Для цитирования:

Гамов Г.А., Смирнов Н.Н., Александрийский В.В., Шарнин В.А. Термическое разложение жидкости для электронных сигарет по данным ИК-спектроскопии. Изв. вузов. Химия и хим. технология. 2017. Т. 60. Вып. 2. С. 7-12.

For citation:

Gamov G.A., Smirnov N.N., Aleksandriiskii V.V., Sharnin V.A. Thermal decomposition of electronic cigarette liquid. Ir study. Izv. Vyssh. Uchebn. Zaved. Khim. Khim. Tekhnol. 2017. V. 60. N 2. P. 7-12.

Г.А. Гамов, Н.Н. Смирнов, В.В. Александрийский, В.А. Шарнин

Георгий Александрович Гамов (区)

НИИ термодинамики и кинетики химических процессов, Ивановский государственный химико-технологический университет, Шереметевский пр., 7, Иваново, Россия, 153000

E-mail: georgegamov38@gmail.com (《)

\title{
Николай Николаевич Смирнов
}

Кафедра технологии неорганических веществ, Ивановский государственный химико-технологический университет, Шереметевский пр., 7, Иваново, Россия, 153000

E-mail: tis@ isuct.ru

Виктор Вениаминович Александрийский, Валентин Аркадьевич Шарнин

НИИ термодинамики и кинетики химических процессов, Ивановский государственный химико-технологический университет, Шереметевский пр., 7, Иваново, Россия, 153000

Институт химии растворов им. Г.А. Крестова, Российская академия наук, ул. Академическая, 1, Иваново, Россия, 153045

E-mail:nmr@isuct.ru, sharn@isuct.ru

\section{ТЕРМИЧЕСКОЕ РАЗЛОЖЕНИЕ ЖИДКОСТИ ДЛЯ ЭЛЕКТРОННЫХ СИГАРЕТ ПО ДАННЫМ ИК-СПЕКТРОСКОПИИ}

В условиях, создающихся при использовании электронных сигарет, химические соединения, содержащиеся в них (никотин (0-2 масс. \%), пропиленгликоль, глицерин, дистиллированная вода и различные ароматизаторы), могут разлагаться, и продукты разложения способны взаимодействовать друг с другом. Таким образом, могут выделяться вредные вещества и канцерогены. Встречаются эксперименты, в которых было обнаружено образование нитрозаминов, специфичных для табака, диацетилпропионила, ацетилпропионила, толуола, этилбензола, о-, м-, п-ксилола, формальдегида, ацетальдегида, ацетона, акролеина, глиоксаля.

Настоящая работа описывает исследование состава паров над жидкостью для электронных сигарет без ароматизаторов методом ИК-сиектроскопии. Интервал температур составлял от 20 до $400{ }^{\circ}$, использовался ток воздуха и ток аргона. Было установлено, что жндкость для электронных сигарет выделяет преимущественно водяной пар, диоксид углерода, пропиленгликоль и глицерин. В атмосфере аргона при температуре $\sim 350{ }^{\circ}$ С был также обнаружен акролеин. Никаких других химических соединений не было обнаружено ни в жидкой фазе методами ${ }^{1} \mathrm{H},{ }^{13} \mathrm{C}$ ЯМР-спектроскопии после нагревания до $150{ }^{\circ} \mathrm{C}$, ни в парах при температуре ниже $250{ }^{\circ} \mathrm{C}$.

Ключевые слова: жидкость для электронных сигарет, ИК-спектроскопия, ЯМР-спектроскопия, термическое разложение, никотин 


\section{G.A. Gamov, N.N. Smirnov, V.V. Aleksandriiskii, V.A. Sharnin}

George A. Gamov ( $\square)$

Research Institute of Thermodynamics and Kinetics of Chemical Processes, Ivanovo State University of Chemistry and Technology, Sheremetievskiy ave., 7, Ivanovo, 153000, Russia

E-mail: georgegamov38@gmail.com ( $\varangle)$, tis@isuct.ru

Nikolay N. Smirnov

Department of Technology of Inorganic Substances, Ivanovo State University of Chemistry and Technology, Sheremetievskiy ave., 7, Ivanovo, 153000, Russia

E-mail: tis@isuct.ru

Viktor V. Aleksandriiskii, Valentin A. Sharnin

Research Institute of Thermodynamics and Kinetics of Chemical Processes, Ivanovo State University of Chemistry and Technology, Sheremetievskiy ave., 7, Ivanovo, 153000, Russia

G.A. Krestov Institute of Solution Chemistry, Russian Academy of Sciences, Akademicheskaya st., 1, Ivanovo, 153045, Russia

E-mail:nmr@isuct.ru, sharn@isuct.ru

\section{THERMAL DECOMPOSITION OF ELECTRONIC CIGARETTE LIQUID. IR STUDY}

Under the conditions which are characteristic for electron cigarette usage chemicals containing in cigarettes (nicotine (0-2\% weight usually), propylene glycol, glycerol, distilled water and different flavors) are capable to thermal decomposing and the products of decomposition could react with each other. Thus, harmful compounds and carcinogens may evolve. Literature describes a number of experiments detecting the formation of tobacco-specific nitrosamines, diacetyl and acetyl propionyl, toluene, ethyl benzene, o-, m-, p-xylene, formaldehyde, acetaldehyde, acetone, propenal, glyoxal.

The present contribution describes our efforts to study the composition of vapors over the liquids for electronic cigarettes containing no flavors by means of IR-spectroscopy. The temperature range was 20 to $400^{\circ} \mathrm{C}$, and flow of air and argon was used. The electronic cigarette liquid was found to emit aqueous vapor, carbon dioxide, propylene glycol and glycerol mostly. Propenal was also detected in vapors in argon atmosphere at temperature of $\sim 350{ }^{\circ} \mathrm{C}$. No other compounds were found in neither liquid phase by ${ }^{1} \mathrm{H},{ }^{13} \mathrm{C} N \mathrm{NM}$ spectroscopy after heating to $150{ }^{\circ} \mathrm{C}$ or vapors at temperature lower than $250{ }^{\circ} \mathrm{C}$.

Key words: electronic cigarette liquid, IR spectroscopy, NMR spectroscopy, thermal decomposition, nicotine

\section{INTRODUCTION}

Tobacco smoking is one of the most significant preventable causes of mortality in the world $[1,2]$. Each year, smoking leads about 5 million people to their end [3]. The hazards of smoking are related mostly to manifold increased risks of cancer development of different king including lung [4], kidney [5], larynx [6], bladder [7], stomach cancer [8] and some others. Smoking also provides cardiovascular diseases $[9,10]$. One should keep in mind that the carcinogenesis could be caused by not only tobacco combustion products but also nicotine itself [11]. Smoking harm reduction and the perspective smoking cessation are among the actual problems of modern healthcare.

Since the moment of their invention in 2004, electronic cigarette is advertised as the safe alternative for conventional cigarettes. However, to the date it is still unknown does whether electronic cigarette exclude completely all the risks intrinsic to the traditional smoking [12-15]. The liquids for electronic cigarettes (ECIG) consist of nicotine ( $0-2 \%$ weight usually), propylene glycol, glycerol, distilled water and, optionally, flavors. In the aerosol composition produced by ECIG, the researcher found nicotine (both free base and protonated species) [16], tobacco-specific nitrosamines (in the case if they are in ECIG liquid initially) [17], 
diacetyl and acetyl propionyl (by the indirect method, presumably) [18], toluene, ethyl benzene, $o$-, $m$-, $p$-xylene [19], formaldehyde, acetaldehyde, acetone, propenal [20, 21], glyoxal [22]. The data on vapors composition above ECIG liquids are not so large and detailed, and the call of F. Henkler and A. Luch «More extensive tests for e-cigarettes» outgoing from "Nature" pages [23] is fully justified.

The main aim of the present work is determining the products of ECIG liquid thermal decomposition. In order to reach this goal, the IR spectral study of vapors forming above commercially available ECIG liquid at its heating was performed. The composition of purchased ECIG liquid was confirmed employing ${ }^{1} \mathrm{H}$ and ${ }^{13} \mathrm{C}$ NMR spectroscopy.

\section{EXPERIMENTAL}

The ECIG liquid was used without preliminary preparations. Its composition claimed by manufacturer was follows: $55 \%$ weight of propylene glycol, $35 \%$ weight of glycerol, $10 \%$ weight of distilled water. Stated concentration of nicotine was $1.8 \mathrm{mg} / \mathrm{ml}$. The liquid contained no flavors.

${ }^{1} \mathrm{H}$ and ${ }^{13} \mathrm{C}$ NMR spectra of ECIG liquid were recorded on Avance III Bruker 500 spectrometer with operating frequencies on proton of $500.17 \mathrm{MHz}$ and ${ }^{13} \mathrm{C}$ of $125.77 \mathrm{MHz}$ at $298.2 \mathrm{~K}$ temperature. The $5 \mathrm{~mm}$ 1H/31P/D-BBz-GRD Triple Resonance Broad Band Probe (TBI) was employed. The mixture of nitromethane, hexamethyl disyloxane and DMSO-d6 was used as external standard. Experimental error of chemical shift measurements did not exceed $0.001 \mathrm{ppm}$, the accuracy of temperature maintaining was $0.1 \mathrm{~K}$ using BVT-3000 thermostating unit. NMR signals identification was done employing predicted spectra [24] and the literature data [25-27].

Vibrational spectra within the range of 400$4000 \mathrm{~cm}^{-1}$ were registered using FT-IR spectrophotometer of Tensor 27 (Bruker Optics, Germany). The resolution of apparatus was $5 \mathrm{~cm}^{-1}$, the error of wavenumber measurement did not exceed $1 \mathrm{~cm}^{-1}$.

\section{RESULTS AND DISCUSSION}

The ${ }^{13} \mathrm{C}$ NMR spectrum obtained for ECIG liquid fits well enough the literature data for nicotine dissolved in $\mathrm{D}_{2} \mathrm{O}$ at $\mathrm{pD}$ approximately corresponding the isoelectric point [25]. The observed deviations of chemical shifts $\delta\left(\mathrm{C}_{2}\right)=147.322(150.0[25]), \delta\left(\mathrm{C}_{3}\right)=$ 137.125 (129.9 [25]), $\delta\left(\mathrm{C}_{4}\right)=135.890$ (138.4 [25]), $\delta\left(\mathrm{C}_{5}\right)=123.859(125.9[25]), \delta\left(\mathrm{C}_{6}\right)=147.676(151.2$ [25]) are related to the differences of solvent properties. We were able to distinguish and assign the carbon signals of pyrrolidinyl group: $\delta\left(\mathrm{C}_{2}{ }^{\prime}\right)=65.377(69.2$ pred. [24]), $\delta\left(\mathrm{C}_{3^{\prime}}\right)=33.248\left(35.06\right.$ pred. [24]), $\delta\left(\mathrm{C}_{4^{\prime}}\right)=$ 21.288 (22.64 pred. [24]), $\delta\left(\mathrm{C}_{5}\right)=55.902$ (57.1 pred. [24]), $\delta\left(\underline{\mathrm{CH}}_{3}\right)=39.148$ (40.46 pred. [24]).

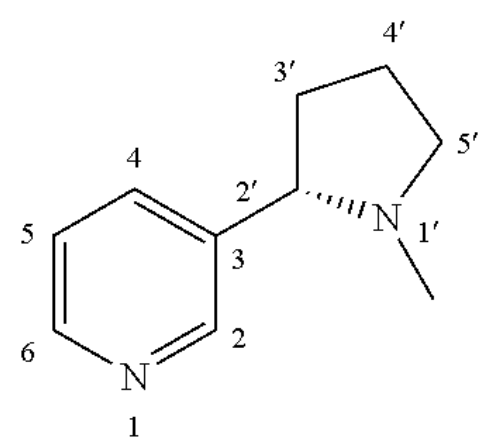

The intensive peaks in the spectral range of 60$75 \mathrm{ppm}$ should be assigned to the nuclei of carbon skeleton of polyhydric alcohols. It is possible to observe for glycerol the $\delta(\underline{\mathrm{C}} \mathrm{H})=71.718$ (75.7 pred. [24], 73.1 [26]) and $\delta\left(\mathrm{CH}_{2}\right)=62.279$ (66.9 pred. [24], 63.5 [26]) signals. Two close lines of $\delta(\underline{\mathrm{CH}})=67.305$ (72.7 pred. [24], 68.2 [27]) and $\delta\left(\mathrm{CH}_{2}\right)=66.504$ (71.6 pred. [24], 67.8 [27]) as well as single peak in higher frequencies range of $\delta\left(\mathrm{CH}_{3}\right)=18.132$ (23 pred. [24], 18.6 [27]) are characteristic of propylene glycol.

In the low frequencies range of proton magnetic resonance spectrum, the signals assigned to the pyridine fragment of nicotine, $\delta\left(\mathrm{H}_{2}\right)=7.973(8.528$ pred. [24]), $\delta\left(\mathrm{H}_{4}\right)=7.363\left(7.777\right.$ pred. [24]), $\delta\left(\mathrm{H}_{5}\right)=$ 6.971 (7.329 pred. [24]), $\delta\left(\mathrm{H}_{6}\right)=7.963$ (8.479 pred. [24]) could be found. Interestingly, the peaks of $\mathrm{H}_{2}$ and $\mathrm{H}_{6}$ atoms are located so close to each other that the $\mathrm{H}_{2}$ singlet overlap with lower frequencies half of $\mathrm{H}_{6}$ doublet. The signals of pyrrolydinyl group of nicotine are poorly distinguishable due to the probable overlapping with polyhydric alcohols protons in the range of 2.8$3.4 \mathrm{ppm}$, except for $-\mathrm{CH}_{3}$-group $(\delta=1.619$, pred. 2.391 [24]). The intensive singlet at $\sim 4.6 \mathrm{ppm}$ should be referred to nitromethane of external standard. Water from ECIG liquid gives broadened peak with maximum at $4.7 \mathrm{ppm}$.

There are no other signals in the ${ }^{1} \mathrm{H},{ }^{13} \mathrm{C}$ NMR spectra. It means that the content of impurities is beyond the detection limits of the analysis method.

We should note that the ECIG liquid heated to $150{ }^{\circ} \mathrm{C}$ and then cooled to the room temperature gave the same ${ }^{1} \mathrm{H}$ and ${ }^{13} \mathrm{C}$ NMR spectra as one before being heated.

When the ECIG liquid is heated in the medium of inert gas, it is possible to distinguish 3 temperature intervals, where the gaseous products of pyrolysis evolve intensively. In the first temperature range of 40$139{ }^{\circ} \mathrm{C}$ with maximum at $102{ }^{\circ} \mathrm{C}$, water is evaporated mostly (Fig. 1). Besides water, the significant amount of carbon dioxide could be observed in spectrum as well as 
little quantities of propylene glycol or glycerol. The presence of propylene glycol is more likely considering its boiling point lower by $\sim 100{ }^{\circ} \mathrm{C}$ than that of glycerol.

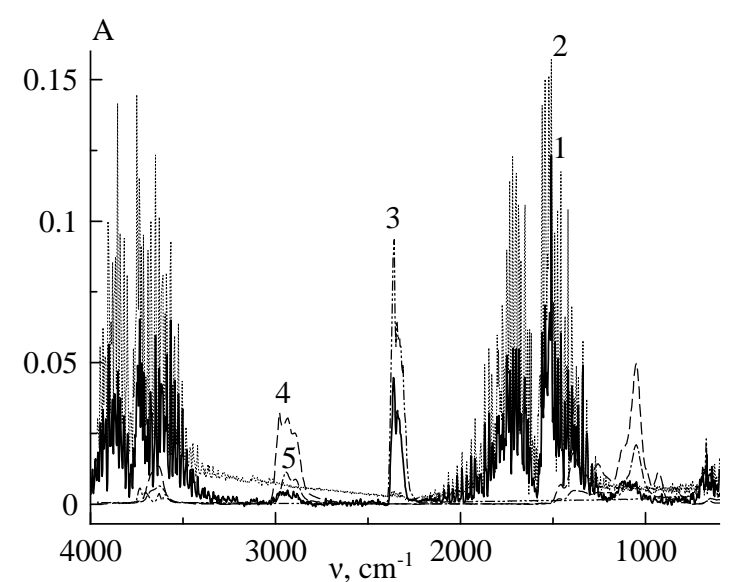

Fig. 1. IR spectrum of gaseous products of ECIG liquid pyrolysis in argon atmosphere at $102{ }^{\circ} \mathrm{C}: 1$ - experimental, 2 - water [28], 3 carbon dioxide [28], 4 - propylene glycol [28], 5 - glycerol [28] Рис. 1. ИК спектр газообразных продуктов термического разложения жидкости для электронных сигарет в атмосфере аргона при $102{ }^{\circ} \mathrm{C}: 1$ - экспериментальная кривая, 2 - вода [28], 3 - диоксид углерода [28], 4 - пропиленгликоль [28], 5 - глицерин [28]

Within temperature range of $140-300^{\circ} \mathrm{C}$, water does not evaporate anymore while the emission of carbon dioxide and polyhydric alcohols grows (Fig. 2).

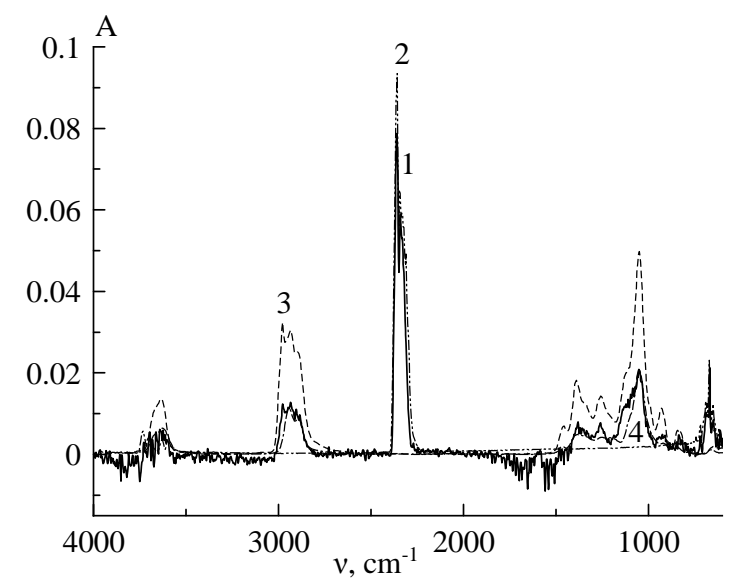

Fig. 2. IR spectrum of gaseous products of ECIG liquid pyrolysis in argon atmosphere at $178{ }^{\circ} \mathrm{C}: 1$ - experimental, 2 - carbon dioxide [28], 3 - propylene glycol [28], 4 - glycerol [28]

Рис. 2. ИК спектр газообразных продуктов термического разложения жидкости для электронных сигарет в атмосфере аргона при $178{ }^{\circ} \mathrm{C}: 1$ - экспериментальная кривая, 2 - диоксид углерода [28], 3 - пропиленгликоль [28], 4 - глицерин [28]

Finally, at the temperature higher than $300^{\circ} \mathrm{C}$, the transmittance lines of glycerol decomposition products, propenal and water, appear in IR spectrum of ECIG liquid vapors (Fig. 3).

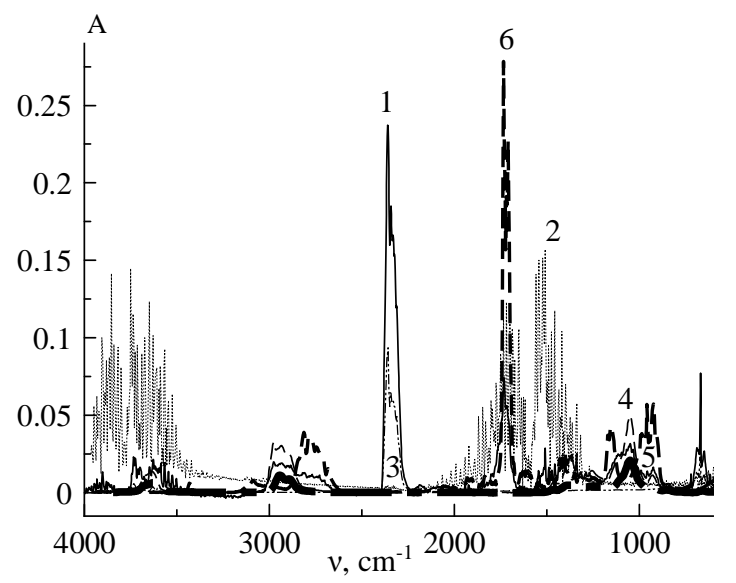

Fig. 3. IR spectrum of gaseous products of ECIG liquid pyrolysis in argon atmosphere at $348{ }^{\circ} \mathrm{C}: 1$ - experimental, 2 - water [28], 3 - carbon dioxide [28], 4 - propylene glycol [28], 5 - glycerol [28], 6 - propenal [28]

Рис. 3. ИК спектр газообразных продуктов термического разложения жидкости для электронных сигарет в атмосфере аргона при $348{ }^{\circ} \mathrm{C}: 1$ - экспериментальная кривая, 2 - вода [28], 3 - диоксид углерода [28], 4 - пропиленгликоль [28], 5 - глицерин [28], 6 - пропеналь [28]

Besides, the ECIG liquid probably emits some diacetyl or acetyl propionyl possessing peaks at $\sim 1360 \mathrm{~cm}^{-1}$ and $\sim 1100 \mathrm{~cm}^{-1}$. Note that we were unable to detect the nicotine in IR spectra of gaseous products of ECIG liquid pyrolysis.

The heating of ECIG liquid in the air atmosphere seems to reflect the processes occurring in ECIG in way that is more realistic. The pyrolysis products evolving proceeds in two stages. In the temperature range of $45-278^{\circ} \mathrm{C}$ with maximum at $216^{\circ} \mathrm{C}$, the liquid emits mostly the aqueous vapor and carbon dioxide (Fig. 4).

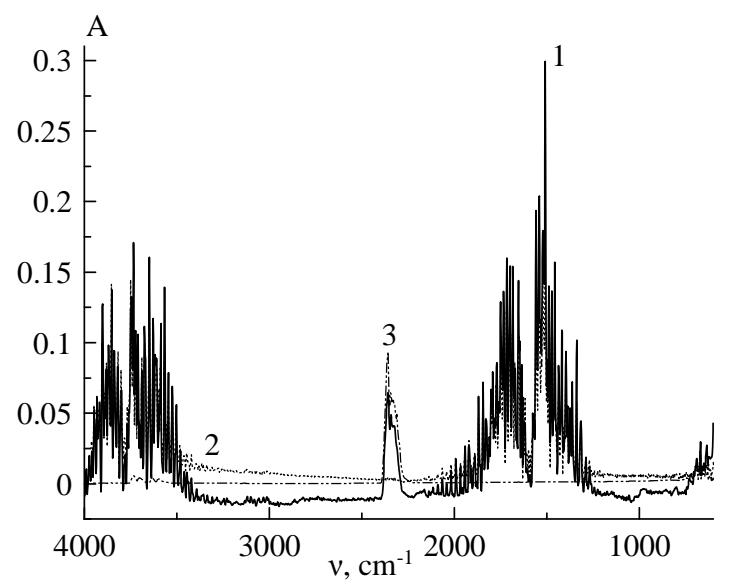

Fig. 4. IR spectrum of gaseous products of ECIG liquid pyrolysis in air atmosphere at $216{ }^{\circ} \mathrm{C}: 1$ - experimental, 2 - water [28], 3 - carbon dioxide [28]

Рис. 4. ИК спектр газообразных продуктов термического разложения жидкости для электронных сигарет на воздухе при $216{ }^{\circ} \mathrm{C}: 1$ - экспериментальная кривая, 2 - вода [28], 3 - диоксид углерода [28] 
Perhaps, the organic compounds (if they evolve) are oxidized by air oxygen producing water and $\mathrm{CO}_{2}$.

Rising the temperature to the values higher than $278{ }^{\circ} \mathrm{C}$, we observed the polyhydric alcohol peaks in the IR spectra of ECIG liquid vapors (Fig. 5).

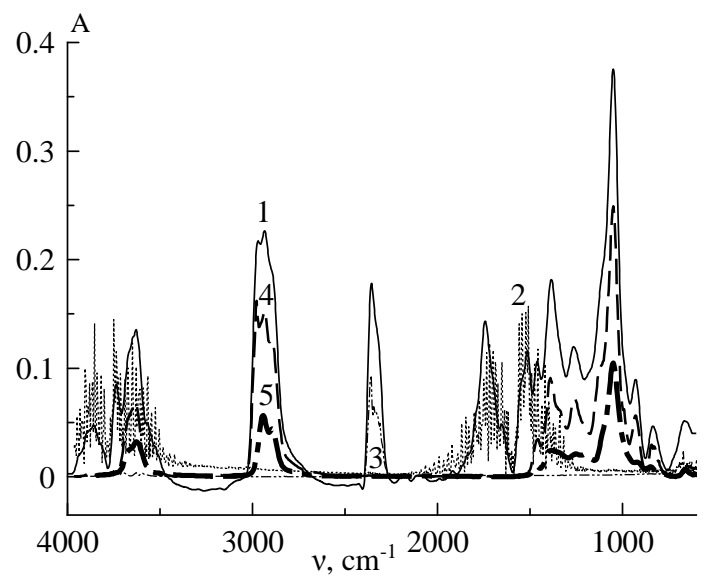

Fig. 5. IR spectrum of gaseous products of ECIG liquid pyrolysis in air atmosphere at $301{ }^{\circ} \mathrm{C}$ : 1 - experimental, 2 - water [28], 3 carbon dioxide [28], 4 - propylene glycol [28], 5 - glycerol [28] Рис. 5. ИК спектр газообразных продуктов термического разложения жидкости для электронных сигарет на воздухе при $301{ }^{\circ} \mathrm{C}: 1$ - экспериментальная кривая, 2 - вода [28], 3 - диоксид углерода [28], 4 - пропиленгликоль [28], 5 - глицерин [28]

Taking into account the fact that the temperature of electronic cigarette heating unit does not exceed $250{ }^{\circ} \mathrm{C}[29]$, the data obtained at lower temperatures only are of some practical interest. In the IR spectra of ECIG liquid at $\mathrm{t}<250^{\circ} \mathrm{C}$ one could observe water, carbon dioxide, propylene glycol, glycerol and nothing more. Any other impurities were emitted in amounts less than detection limits of method. The probability of acute poisoning of human beings by toxic products of ECIG liquid pyrolysis could be apparently neglected.

It is worth noting that there is a number of articles describing the thermal decomposition of tobacco [e. g. 30-32]. The authors used the experimental conditions and methods similar with ones we have used for studying the electronic cigarette liquid. In the products of tobacco combustion, they have found the large amounts of carbonyl compounds of different structure [30-32], acetaldehyde [31], carbon monoxide [30-32], mixture of phenolic compounds [30,32], formic acid [30], ammonia [32], hydrogen cyanide [30] and propanal [30]. These toxic components were not detected in the presented study.

\section{CONCLUSIONS}

The vapors above heated liquid for electronic cigarettes were studied by IR spectroscopy in the argon and air. Under experimental condition, aqueous vapor, propylene glycol, glycerol and carbon dioxide were detected. No other compounds were found in neither liquid phase by ${ }^{1} \mathrm{H},{ }^{13} \mathrm{C}$ NMR spectroscopy after heating to $150^{\circ} \mathrm{C}$ nor vapors at temperature lower than $250^{\circ} \mathrm{C}$. The probability of acute poisoning of human beings by toxic products of ECIG liquid pyrolysis could be apparently neglected.

In the same time, the danger of the toxic compounds evolving of concentrations lower than experimental method detection limits still exists.

\section{REFERENCES}

1. http://www.who.int/tobacco/mpower/mpower_report_ full_2008.pdf (Accessed 02.11.2015)

2. Samet J.M. Tobacco smoking: the leading cause of preventable disease worldwide. Thorac. Surg. Clin. 2013. V. 23. N 2. P. 103-112. DOI: 10.1016/j.thorsurg.2013.01.009.

3. Rizzuto D., Fratiglioni L. Lifestyle factors related to mortality and survival: A mini-review. Gerontology. 2014. V. 60. N 4. P. 327-335. DOI: 10.1159/000356771.

4. Stein C.J., Colditz G.A. Modifiable risk factors for cancer. Brit. J. Canc. 2004. V. 90. P. 299-303. DOI: 10.1038/sj.bjc.6601509.

5. Lipworth L., Tarone R.E., McLaughlin J.K. The epidemiology of renal cell carcinoma. J. Urology. 2006. V. 176. N 6. P. 2353-2358. DOI: 10.1016/j.juro.2006.07.130.

6. Ridge J.A., Mehra R., Lango M.N., Feigenberg S. Head and Neck Tumors. Cancer Management: A Multidisciplinary Approach. 14 ed. 2014.

7. Boffetta P. Tobacco smoking and risk of bladder cancer. Scand. J. Urol. Nephr. 2008. V. 42. Suppl. 218. P. 45-54. DOI: $10.1080 / 03008880802283664$.

8. Kuper H., Boffetta P., Adami H.-O. Tobacco use and cancer causation: association by tumor type. J. Intern. Med. 2002. V. 252. P. 206-224. DOI: 10.1046/j.13652796.2002.01022.x.

9. Shah R.S., Cole J.W. Smoking and stroke: the more you smoke the more you stroke. Exp. Rev. Cardiovasc. Ther. 2010. V. 8. N 7. P. 917-932. DOI: 10.1586/erc.10.56.

10. Narkiewicz K., Kjeldsen S.E., Hedner T. Is smoking a causative factor of hypertension? Blood Press. 2005. V. 14. N 2. P. 69-71. DOI: 10.1080/08037050510034202.

11. Grando S.A. Connections of nicotine to cancer. Nat. Rev. Cancer. 2014. V. 14. N 6. P. 419-429. DOI: $10.1038 /$ nrc3725.

12. Ebbert O., Agunwamba A.A., Rutten L.J. Counseling patients on the use of electronic cigarettes. Mayo Clinic Proc. 2015. V. 90. N 1. P. 128-134. DOI: $10.1016 /$ j.mayocp.2014.11.004.

13. Harrell P.T., Simmons V.N., Correa J.B., Padhya T.A., Brandon T.H. Electronic nicotine delivery systems ("E-cigarettes"): Review of safety and smoking cessation efficacy. Otolaryngol. Head Neck Surg. 2014. V. 151. N 3. P. 381-393. DOI: 10.1177/0194599814536847.

14. Siu A.L. Behavioral and pharmacotherapy interventions for tobacco smoking cessation in adults, including pregnant women: U.S. Preventive Services Task Force recommendation statement. Ann. Intern. Med. 2015. V. 163. N 8. P. 622-634. DOI: 10.7326/M15-2023.

15. Blaser J., Cornuz J. Experts' consensus on use of electronic cigarettes: a Delphi survey from Switzerland. BMJ. 
Open. 2015. V. 5. P. e007197. DOI: 10.1136/bmjopen2014-007197.

16. El-Hellani A., El-Hage R., Baalbaki R., Salman R., Talih S., Shihadeh A., Saliba N.A. Free-base and protonated nicotine in electronic cigarette liquids and aerosols. Chem. Res. Toxicol. 2015. V. 28. N 8. P. 1532-1537. DOI: 10.1021/acs.chemrestox.5b00107.

17. Farsalinos K.E., Gillman G., Poulas K., Voudris V. Tobacco-specific nitrosamines in electronic cigarettes: comparison between liquid and aerosol levels. Int. J. Environ. Res. Public Health. 2015. V. 12. P. 9046-9053. DOI: 10.3390/ijerph120809046.

18. Farsalinos K.E., Kistler K.A., Gillman G., Voudris V. Evaluation of electronic cigarette liquids and aerosol for the presence of selected inhalation toxins. Nicotine \& Tobacco Res. 2015. V. 17. N 2. P. 168-174. DOI: 10.1093/ntr/ntu176.

19. Czogala J., Goniewicz M.L., Fidelus B., ZielinskaDanch W., Travers M.J., Sobczak A. Secondhand exposure to vapors from electronic cigarettes. Nicotine \& Tobacco Res. 2014. V. 16. N 6. P. 655-662. DOI: 10.1093/ntr/ntt203.

20. Goniewicz M.L., Knysak J., Gawron M., Kosmider L., Sobczak A., Kurek J., Prokopowicz A., JablonskaCzapla M., Rosik-Dulewska C., Havel C., Jacob III P., Benowitz N. Levels of selected carcinogens and toxicants in vapor from electronic cigarettes. Nicotine \& Tobacco Res. 2014. V. 13. N 2. P. 133-139. DOI: 10.1136/tobaccocontrol-2012-050859.

21. Geiss O., Bianchi I., Barahona F., Barrero-Moreno J. Characterisation of mainstream and passive vapours emitted by selected electronic cigarettes. Int. J. Hyg. Environ. Health. 2015. V. 218. P. 169-180. DOI: 10.1016/j.ijheh.2014.10.001.

22. Bekki K., Uchiyama S., Ohta K., Inaba Y., Nakagome H., Kunugita N. Carbonyl compounds generated from electronic cigarettes. Int. J. Environ. Res. Public Health. 2014. V. 11. P. 11192-11200. DOI: 10.3390/ijerph111111192.
23. Henkler F., Luch A. Safety regulations: More extensive tests for e-cigarettes. Nature. 2015. V. 525. P. 187. DOI: $10.1038 / 525187 \mathrm{~d}$.

24. http://www.nmrdb.org/ (Accessed 03.11.2015)

25. Slaven R.V. The carbon-13 and proton NMR spectra of nicotine in aqueous media. J. Heterocycl. Chem. 1984. V. 21. N 5. P. 1329-1332. DOI: 10.1002/jhet.5570210516.

26. Nassif N., Roux C., Coradin T., Rager M.-N., Bouvet O.M.M., Livage J. A sol-gel matrix to preserve the viability of encapsulated bacteria. J. Mater. Chem. 2003. V. 13. P. 203-208. DOI: 10.1039/B210167J.

27. Salarian M., Xu W.Z., Biesinger M.C., Charpentier P.A. Synthesis and characterization of novel $\mathrm{TiO}_{2-}$ poly(propylene fumarate) nanocomposites for bone cementation. J. Mater. Chem. B. 2014. V. 2. P. 5145-5156. DOI: $10.1039 / \mathrm{C} 4 \mathrm{~TB} 00715 \mathrm{H}$.

28. http://webbook.nist.gov/chemistry/ Accessed 06.11.2015.

29. Rowell T.R., Tarran R. Will chronic E-cigarette use cause lung disease? Am. J. Physiol. - Lung Cell. Mol. Physiol. 2015. DOI: 10.1152/ajplung.00272.2015.

30. Polat S., Apaydin-Varol E., Putun A.E. Thermal decomposition behavior of tobacco stem Part I: TGAFTIR-MS analysis. Energy Sources, Part A: Recovery, Utilization, and Environmental Effects. 2016. V. 38. N 20. P. 3065-3072. DOI: 10.1080/15567036.2015.1129373.

31. Barontini F., Tugnoli A., Cozzani V., Tetteh J., Jarriault M., Zinovik I. Volatile products formed in the thermal decomposition of a tobacco substrate. Ind. Eng. Chem. Res. 2013. V. 52. P. 14984-14997. DOI: 10.1021/ie401826u.

32. Zhou S., Ning M., Xu Y., Shu J., Wang C., Hu Y., Ge S., Tian Z., She S., Heet Q. Effects of melamine phosphate on the thermal decomposition and combustion behavior of reconstituted tobacco sheet. J. Therm. Anal. Cal. 2013. V. 112. N 3. P. 1269-1276. DOI: 10.1007/s10973-0122674-y.

Поступила в редакиию 16.09.2016

Принята к опубликованию 14.11.2016

Received 16.09.2016

Accepted 14.11.2016 